\title{
Identification of Arbuscular Mychorizae Fungi on Oil Palm in Bireuen, Aceh
}

\author{
Zaitun Ritaqwin*, Mizan Maulana, Nazalia \\ Agriculture Science Department, Faculty of Agriculture and Animal Sciences, Islamic National University of \\ Indonesia, Bireuen, Aceh, Indonesia \\ *Corresponding author. Email: zaitunritaqwin@gmail.com
}

\begin{abstract}
Oil palm plantations in Aceh, especially in Bireuen, are generally planted on red-yellow podzolic soil types. Arbuscular mycorrhizal fungi (AMF) are fungi who are symbiotically associated with $97 \%$ of plant species. This study aims to identify the type and population of mycorrhizal spores from oil palm rhizosphere soil samples using culture trapping techniques (maize, sorghum, kudzu). This research was carried out in a greenhouse and Experimental Field, Faculty of Agriculture, Islamic National University of Indonesia, Bireuen, Aceh. Isolation, identification and observation of AMF colonization on plant roots was carried out at the Laboratory of Soil Biology, Faculty of Agriculture, Syiah Kuala University. The parameters included the number of arbuscular mycorrhizal fungi spores and the percentage of root colonization using the trapping culture method. The trapping culture method used $50 \mathrm{~g}$ of soil samples on oil palm rhizosphere which aged 5 months, 7 years, 9 years and 12 years. The results showed that the most dominant mycorrhizae found was the Glomus type. The mycorrhizae spores types found in the trapping culture were Glomus, Acaulospora and Gigaspora. The host plant that produced the most AMF spores was sorghum, while the highest AMF colonization of the three host plants was found in the roots of maize plants (78\%) with very high criteria.
\end{abstract}

Keywords: Oil palm, Culture trapping, AMF

\section{Introduction}

Oil palm (Elaeis guineensis Jacq.) is one of the prima donnas of plantation crops that have high economic value. In addition, Indonesia has the largest oil palm area in the world, which is $34.18 \%$ of the world's oil palm area [1,2]. The development of oil palm plantations in Indonesia is challenged with limited fertile lands, with the result that the expansion of the area is more directed at marginal lands which are usually found in areas outside Java such as Aceh, Sumatra, Java and Sulawesi. Generally the soil in these areas is dominated by Ultisols, Oxisols, and Inceptisols. Ultisol soils or better known as red-yellow podzolic soil is one type of soil that is less fertile used in agriculture [3].

According to Kurnia et al. (2019) [4], several factors affect plant growth, namely temperature, light, water, nutrients and soil. Furthermore, undoubtedly the most influential factor on plant growth is soil. Fertile soil is determined by the existence of a mutually beneficial relationship between roots and fungi commonly known as mycorrhizae. Mycorrhizae are fungi that live in mutualistic symbiosis with plant roots [2]. Several studies have shown that arbuscular mycorrhizal fungi have symbiotic mutualism in maize [5], sorghum [6], Pueraria javanica [7], oil palms [8]. grasses and legumes [9], Pericopis mooniana [10], cacao (Theobroma cacao L.) [11], sweet potatoes (Ipomoea batata L.) and cassava (Manihot esculenta Crantz) [12].

Generally, mycorrhizae are divided into three groups, namely: endomycorrhizae or arbuscular mycorrhizal fungi (AMF), ectomycorrhizae, and ectendomycorrhiza. Basri (2019)[13] stated that mycorrhizae can be symbiotic between plant roots that are commonly found in the natural 
environment and can produce various benefits for the host plants. The advantages of mycorrhizae are clearly identified in soil conditions that are infertile in nutrients or in dry conditions, but in fertile soil conditions the role of mycorrhizae is not so significant [8].

Information about the presence of AMF in Aceh, especially in Bireuen Regency is still limited, hence it is necessary to conduct a series of studies to determine the presence of arbuscular mycorrhizal fungi (AMF) in the rhizosphere of oil palm plants in Bireuen Regency by using culture trapping techniques. The purpose of this study was as a preliminary research to determine the presence of arbuscular mycorrhizal fungi (AMF) in the rhizosphere of oil palm plants in Bireuen Regency using trapping culture techniques, and the advantage of this research is to increase knowledge about indigenous spore genera that can be developed into mycorrhizal biofertilizer.

\section{Material and Methods}

\subsection{Location and time of research}

The study was carried out from January to May 2021. The trapping of AMF was carried out in the greenhouse of the Experimental Garden of the Islamic National University of Indonesia, where the isolation and observation of AMF colonization on plant roots was carried out at the Soil Biology Laboratory, Faculty of Agriculture, Syiah Kuala University.

\subsection{Materials and Tools}

\subsubsection{Materials}

The materials used in this study were soil samples from the rhizosphere of oil palm plants in farmer smallholder plantations at various ages (5 months, 7 years, 9 years and 12 years), maize seeds (Zea mays L.), sorghum seeds (Sorghum bicolor L.), Kudzu seeds (Pueraria javanica), 60\% glucose solution, polyvinyl lacto glycerol (PVLG) solution, blue ink (Quink Parker), $\mathrm{H}_{2} \mathrm{O}_{2}$ solution (3\%), $\mathrm{KOH}$ solution (10\%), fertilizer, sugar, river sand, aquadest and acetic acid solution (5\%).

\subsubsection{Tools}

The tools used in this study were pots with a volume of $200 \mathrm{~cm}^{3}$, a set of sieves measuring (600 $\mu \mathrm{m}, 250 \mu \mathrm{m}, 106 \mu \mathrm{m}, 53 \mu \mathrm{m}$ and $38 \mu \mathrm{m}$ ), analytical balance, centrifuge, petri dish, spore tweezers, optical microscope, slide glasses [14].

\subsection{Research methods}

This research is an exploration study of arbuscular mycorrhizal fungi through trapping culture (captivity) [14]

\subsection{Soil sampling in oil palm root rhizosphere}

Sampling of soil and oil palm roots was carried out on the rhizosphere of oil palm at several plant ages ( 5 months, 7 years, 9 years and 12 years) taken at a depth of $0-20 \mathrm{~cm}$. The sampling locations for oil palms aged 5 months and 7 years were in Krueng Simpo Village, and 9 years and 12 years old in Cot Panglima Village. Each plant age consisted of five points as replicates and the determination of the sampling points of the soil was carried out randomly. At each sampling point 1 $\mathrm{kg}$ of soil sample was taken out by following the method of Brundrett et al. (1996) [14].

\subsection{Trapping Culture}

The trapping culture technique was carried out by following the method of Brundrett et al. (1996) [14]. 


\subsubsection{Preparation of planting media}

The growing media used for trapping culture consisted of sterilized river sand and soil samples from the oil palm rhizosphere. The composition of the planting medium used was $50 \mathrm{~g}$ of sand, $50 \mathrm{~g}$ of soil samples and $50 \mathrm{~g}$ of sand. The planting medium was placed in a culture pot which was first rinsed with clorox solution $(0.05 \%)$. Each culture pot was prepared in duplicate for each point of soil sampling [14].

\subsubsection{Preparation and planting of host plant seeds}

Before sowing, maize, sorghum and kudzu seeds were soaked in clorox solution $(0.05 \%)$ for 10 minutes. Furthermore, the seeds were rinsed with clean water and soaked in warm water $\left(45^{\circ} \mathrm{C}\right)$ for 24 hours to stimulate seed germination. Then the seeds are sown on trays measuring $20 \times 30 \mathrm{~cm}$ using sterile sand media. Watering is done every morning approximately $50 \mathrm{ml}$ per tray. Seedlings are ready to be transferred to culture pots once the plant has two to three leaves [14].

\subsection{Maintenance of Host Plants}

\subsubsection{Watering}

The plants were watered every afternoon with $20 \mathrm{ml} / \mathrm{L}$ of Reverse Osmosis (RO) water per plant pot [14].

\subsubsection{Fertilization}

Fertilization with Hyponex NPK 25-5-20 fertilizer at a concentration of $1 \mathrm{~g} / \mathrm{L}$ was carried out once a week after the plants were seven days old. The nutrient solution was given approximately $25 \mathrm{ml}$ in each culture pot.

\subsubsection{Pest control}

Pest control is done mechanically.

\subsubsection{Stressing and harvesting spores}

After the maize, sorghum and kudzu plant cultures were three months old, watering activities were stopped to condition the culture under drought stress conditions in order to stimulate the formation of AMF spores. Next, cut the top of the plant after the plant produces flowers or enters generative development, then stress was carried out. Drying was carried out for approximately two weeks, the plants were disassembled from the growing media for spore isolation [14].

\subsection{Parameters}

\subsubsection{Number and types of spores of arbuscular mycorrhizal fungi}

Calculation of the number of spores begins with the pour-filter technique method by Pacioni (1992) [15] in Brundrett et al. (1996) [14]. The working procedure of this filter casting technique is followed by the centrifugation technique [14]. AMF spore types were identified using the method of Brundrett et al. (1996) [14]. Procedure for isolation and identification of AMF spores.

\subsubsection{Observation of root colonization}

Observation of root infection in sample plants (roots of host plants for experiment) was carried out using root staining techniques (Kormanik and MCGraw (1982) [16] in Brundrett et al. (1996) [14]. The calculation of the percentage of root colonization.

Calculation of the percentage of root colonization using the formula Giovanneti and Mosse (1980) [17] in Brundrett et al. (1996) [14] as follows: 


$$
\text { Mycorrhizal infection }(\%)=\frac{\text { Number of infected root area }}{\text { Total area of the roots observed }} \times 100 \%
$$

\subsection{Data analysis}

Observations were analyzed descriptively in tabular form by comparing the data on the number of spores, types of spores, and root colonization obtained from trapping cultures on maize, sorghum and kudzu.

\section{Results and Discussion}

\subsection{Result}

\subsubsection{AMF Infection}

The existence of Mycorrhizal Fungi Association can be known by the presence or absence of infection that occurs in plant roots. In general, AMF has several structures to survive in the soil. [8] added, the structures produced by AMF include hyphae, mycelia, vesicles, arbuscules and spores.

Hyphae are one of the structures of AMF which are shaped like fine threads, and function as nutrient absorbers. Mycelia is a collection of hyphae. Arbuscula is a colonizing unit that extends deeper cortical cells and perforates the cell wall, and shapes a complex branching hyphae system, and resembles like a small tree with branches. Vesicles are bulging structures formed on the main hyphae, which function as storage organs and these structures also function as spores [18]. Infections that occur in the roots of the host plant in the trapping culture technique indicate the percentage of infection colonization by AMF in the trapping culture host plants (maize, sorghum, kudzu). From the observations, the structure of AMF infection on the roots of the trapping culture host plants was in the form of hyphae, vesicles and arbuscules.
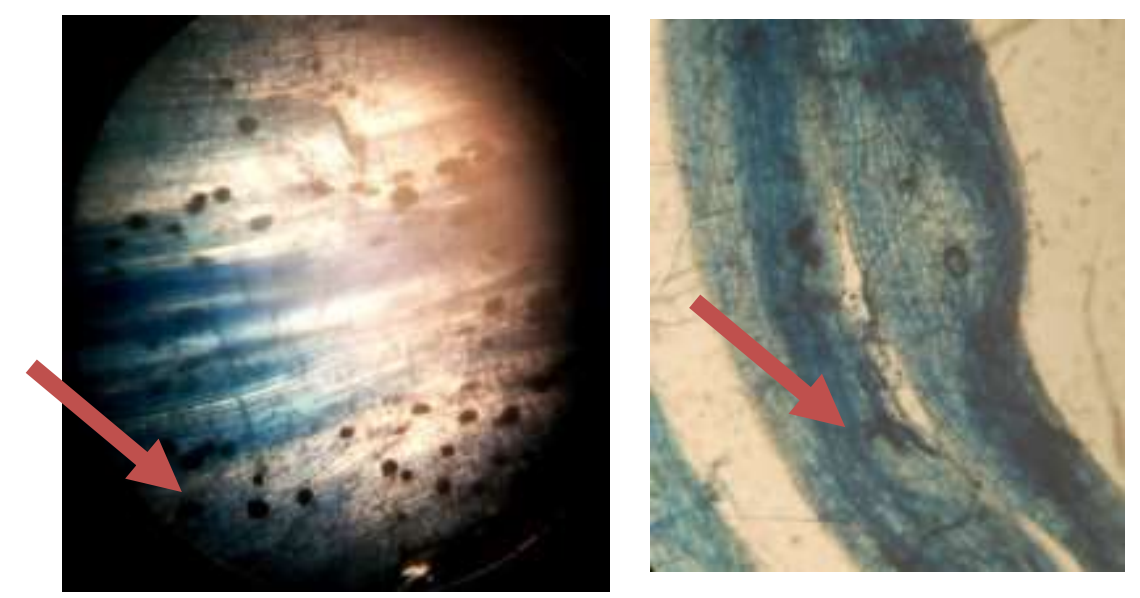

Figure 1

Structure of CMA in root tissue of maize, sorghum, kudzu plants (A) vesicles and

(B) hyphae

The results showed that the host plants in the trapping culture technique (maizes, sorghum, kudzu) were infected by AMF. This indicates that the association between AMF and the roots of the host plant is well developed, although the percentage of infection that occurs in each plant is different. The average percentage of AMF colonization on various host plants in trapping culture can be seen in Figure 2. 


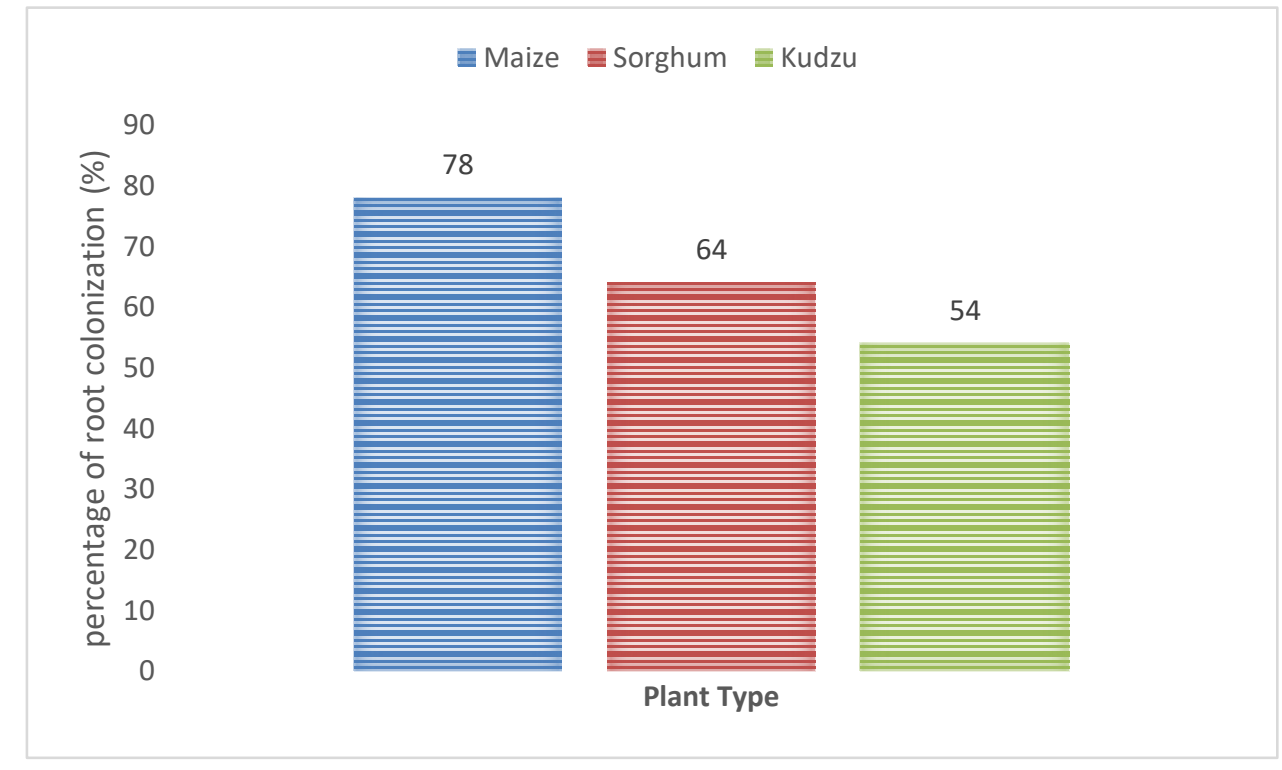

Figure 2

The average percentage of AMF colonization on various host plants in trapping culture

Figure 2 shows the average percentage of the highest AMF colonization on plant roots found in maize. The average percentage of AMF colonization in maize was classified as very high (76$100 \%$ ) while sorghum and kudzu were classified as high (51-75\%). The average percentage of AMF colonization on plant roots was thought to be influenced by root exudates. The same thing is also shown in the results of research [18] which states that each plant has a different percentage of infection due to factors that affect mycorrhizal infection in plants such as the dependence of plants on mycorrhizae, the effectiveness of isolates and nutritional conditions of Phosphor (P) elements. This is supported by research of Manaroinsong and Lolong (2015)[19], that AMF is generally in symbiosis with plants, AMF forms external hyphae to boost the reach of plant roots to absorb nutrients, especially Phosphor, through oil palm roots.

\subsection{Arbuscular Mycorrhizal Fungi Spore Density}

Spore density is the number of spores in $50 \mathrm{~g}$ of oil palm rhizosphere soil. The diversity of AMF spores on various trapping culture host plants (maize, sorghum, kudzu) shown in Table 1. Also, from Table 1 shows the average number of spore types per $50 \mathrm{~g}$ of soil sample at various ages of host plants in trapping culture. Trapping culture technique showed the abudance of AMF for each host plants. This result is supported by the study of Siantur et al. (2015) [20], there was an increasing number of spores in trapping culture when comparing to the spore density before trapping, it was due to stressing treatment or watering stopping treatment which was resulted in a positive effect on the development of AMF.

Table 1.

Average Number of Spores per $50 \mathrm{~g}$ of Soil Sample at Various Age of Host Plants in Trapping Culture

\begin{tabular}{cccc}
\hline \multirow{2}{*}{ Host Plant } & \multicolumn{3}{c}{ Number of Spore Types } \\
\cline { 2 - 4 } & Glomus sp. & Acaulospora $s p$. & Gigaspora $s p$. \\
\hline Maize & 358 & 0 & 1 \\
Sorghum & 1021 & 6 & 7 \\
Kudzu & 291 & 3 & 1 \\
\hline
\end{tabular}


Based on Table 1, there are three genera of AMF spores from the trapping culture method using sorghum and kudzu plants, namely Glomus, Acaulospora and Gigaspora. On the other hand, in maize only two types of AMF spores were found, namely Glomus and Gigaspora. In addition, Sorghum host plants had the highest number and types of spores compared to maize and kudzu host plants. This result is supported by the research results of Prasetia (2012) [21] which showed that the host plant sorghum produced a higher number of spores than maize.

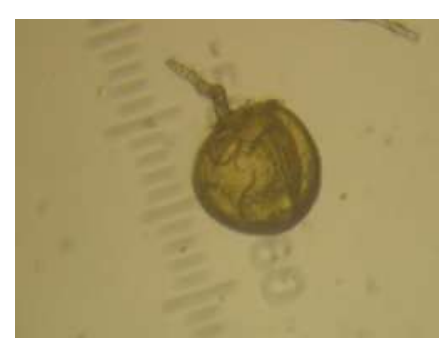

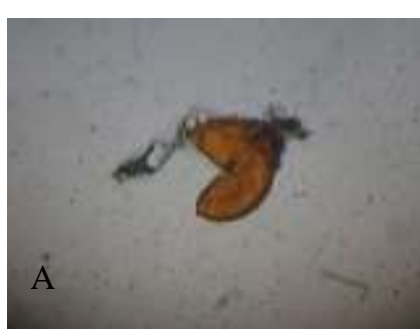

Figure 3.

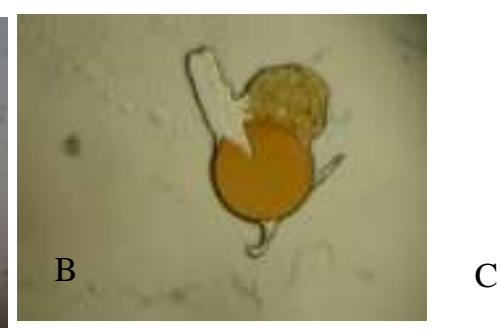

$\mathrm{C}$

The type of AMF in the culture trapping (A) Glomus sp1,(B) Glomus sp3, (C)Glomus sp6

The identification results show that from the picture above, AMF spores of the genus Glomus sp. has different types and characteristics in each genus. AMF spores of the genus Glomus sp. is the most dominant type of spore found in each trapping culture host plant. This is similar with the study of Cahyani et al. (2014) [22] which showed Glomus was the highest abundance AMF spore found compared to Acaulospora and Gigaspora spores on Alluvial soil in Pemakasan Regency, Madura. In addition, according to Sari et al. (2017) [23] mycorrhiza species Acaulospora sp, Sclerocystis and Scutellospora sp. has a lower abundance compared to the type of Glomus sp.

Rahmawati et al 2020 [8] stated that Glomus is an AMF that has an adequate high adaptability to various environmental conditions, both at acidic and neutral $\mathrm{pH}$. According to [24], Acaulospora is a genus of mycorrhizae belonging to the family Acaulosporaceae. Acaulospora genus has various characteristics, the spores formed on the sides of the neck of the Soporiferous Saccule, having 2-3 spore walls, globose to elliptical in shape, hyaline, yellow or yellowish red in color, and the size of spores between 100-400 $\mu \mathrm{m}$. Gigaspora is a genus of mycorrhizae belonging to the family Gigasporaceae. This genus has distinctive characteristics, among others, spores are produced singly in the soil, do not have an inner spore wall layer, have bulbous suspensors, are globose or subglobose, cream to yellow in color, measuring $125-600 \mu \mathrm{m}$ [25].

\section{Conclusion}

The results of this study concluded that there were three AMF genera found in trapping culture plants (maize, sorghum, kudzu), namely Glomus sp, Acaulospora sp and Gigaspora sp. The highest percentage of AMF colonization was found in plant roots on maize, while sorghum host plants had the highest number and types of spores compared to maize and kudzu host plants. From the results of the identification of the mycorrhizal genus and spore population, it can have a positive impact on oil palm plantations. With the aim that the presence of mycorrhizae in the area can reduce the use of chemical fertilizers. 


\section{Acknowledgements}

The author thank all teams of the Islamic National University of Indonesia and Soil Biology Laboratory, Faculty of Agriculture, Syiah Kuala University for all the facilities provided to carry out this research. Also, the author would like to thank the Ministry of Education and Culture for funding this research, especially for the XIII Directorate of Higher Education.

\section{References}

[1] Yan, F.,Widyastuti,Y.E., Satyawibawa, I., \& Paeru., R.H. (2012). Kelapa Sawit. Penebar Swadaya. Jakarta. $236 \mathrm{hlm}$.

[2] Damayanti, N.V., Rini, M.V., \& Evizal, R. (2015). Respon Pertumbuhan Kelapa Sawit Bibit (Elais guineensis Jacq.) terhadap Jenis Fungi Mikoriza Arbuskula pada Dua Tingkat Pemupukan NPK. Jurnal Penelitian Pertanian Terapan, 15(1), 33-40.

[3] Andalusia, B., Zainabun., \& Arabia, T. (2016). Karakteristik Tanah Ordo Ultisol di Perkebunan Kelapa Sawit PT.Perkebunan Nusantara I (Persero) Cot Girek Kabupaten Aceh Utara. Jurnal Kawista, 1(1), 4549.

[4] Kurnia., Gusmiaty., \& Larekeng., S.H. (2019). Identifikasi dan Karakterisasi Mikoriza pada Tegakan Nyatoh (Palaquium sp.). Jurnal Perennial, 15(1), 51-57.

[5] Musfal. (2010). Potensi Cendawan Mikoriza Arbsukula untuk Meningkatkan Hasil Tanaman Jagung. Jurnal Litbang Pertanian, 29(4), 154-158.

[6] Rivanna, E., Indriani, N.P., \& Khairani, L. (2016). Pengaruh Pemupukan Fosfor dan Inokulasi Fungi Mikoriza Arbuskula (FMA) terhadap Pertumbuhan dan Produksi Tanaman Sorgum (Sorghum bicolor L.). Jurnal Ilmu Ternak, 16(1), 46-53.

[7] Prihantoro, I., Rachim, A.F., \& Karti, P.D.M.H. (2017). Efektifitas Perbanyakan Kultur Tunggal Cendawan Mikoriza Arbuskula (Gigaspora margarita, Acaulospora tuberculata) pada Inang Pueraria javanica. Jurnal Pastura, 7(1), 1-3.

[8] Rahmawati, R., Putir, P.E., Damiri, M., Tanduh, Y., \& Nursiah, N. (2020). Keragaman Fungi Mikoriza Arbuskula (FMA) di Lahan Gambut Konversi Hutan Alam Menjadi Perkebunan Kelapa Sawit. Jurnal Hutan Tropika, XV(1), 8-19.

[9] Ansiga, R.E., Rumambi., Kaligis, D., Mansur, I., \& Kaunang, W. (2017). Eksplorasi Fungi Mikoriza Arbuskula (FMA) pada Rizosfer Hijau Pakan. Jurnal Zootek, 37 (1), 167-178.

[10] Husna., Budi, S.W., Mansur, I., Kusmana, C., \& Kramadibrata, K. (2014). Fungi Mikoriza Arbuskula pada Rhizosfer Pericopsis mooniana (Thw).Thw. di Sulawesi Tenggara. Berita Biologi, 13 (3), 263- 273.

[11] Kumalawati, Z., Ridwan, A., \& Kafrawi. (2018). Cendawan Mikoriza Arbuskula pada Rhizosfer Tanaman Kakao ( Theobroma cacao L.) di Tipe Kemiringan Lahan yang Berbeda. Jurnal Agroplantae, 7(2), 1-7.

[12] Widiatma, P.S., Wirawan, I.G.P., \& Susrama, I.G.P. (2015). Identifikasi Mikoriza Arbuskular (MVA) pada Rhizosfer Tanaman Ubi Jalar ( Ipomoea batata L.) dan Ubi Kayu (Manihot esculenta Crantz) serta Perbanyakannya dengan Media Zeolit. E-Jurnal Agroekoteknologi Tropika, 4(4), 253- 263.

[13] Basri, A.H.H. (2018). Kajian Peranan Mikoriza dalam Bidang Pertanian. Jurnal Agrica Ekstensia, 12(2), 74-78

[14] Brundrett, M., Bougher, N., Dell, B., Grave, T., \& Malajezuk, N. (1996). Working with Mycorrhiza in Forestry dan Agriculture. Australian Centre for International Agricultural Research (ACIAR), Canberra.

[15] Pacioni, G. (1992). Wet Sieving and Decanting Techniques for the Extraction of Spore of VA Mycorrhizae Fungi. San Diego (GB), Academic. Pr.Hlm 317-322.

[16] Kormanik, P.P., \& McGraw, A.C. (1982). Quantification of Vesicular-Arbuscular Mycorrhizae in Plant Roots in Methods and Principles of Mycorrhizal Research N.C. Schenk ed. APS Press.Minneapolis.

[17] Giovannetti, M., \& Mosse, B. (1980). An Evaluation of Techniques for Measuring Vesicular Arbuscular Mycorrhizal Infection in Roots. New Phytol. 8, 489-500.

[18] Setiadi, Y., \& Setiawan A. (2011). Studi Status Fungi Mikoriza Arbuskula di Areal Rehabilitas Pasca Penambang Nikel. Jurnal Silvi Kultur Tropika, 03(01), 88-95.

[19] Manaroinsong, E., \& Lolong, A.A. (2015). Identifikasi Cendawan Mikoriza Arbuskula (CMA) pada Beberapa Tekstur Tanah di Lahan Kelapa Sawit di Kalimantan Tengah. Jurnal B.Palma 16(2), 203-210

[20] Siantur, R.P., Delvian., \& Elfiati, D. 2015. Keanekaragaman Mikoriza Arbuskula (FMA) pada Beberapa Tegakan di Areal Arboretum Universitas Sumatera Utara. Jurnal Biologi, 1-10.

[21] Prasetia. D. 2012. Efektivitas media dan tanaman inang untuk perbanyakan fungi mikoriza arbuskular (FMA). Skripsi. Fakultas FMIPA. Universitas Pakuan Bogor. 
[22] Cahyani,N.K.M.D.,Nurhatika, S., \& Muhibuddin, A. (2014). Eksplorasi Mikoriza Vesikula Arbuskula (MVA) Indigenous pada Tanah Aluvial di Kabupaten Pamekasan Madura. Jurnal Sains dan Seni Pomit, 3(1), 2337-3520.

[23] Sari, S., Kumastuti, A., \& Indrawati, W. (2017). Identifikasi Fungi Mikoriza Arbuskar (FMA) Tanaman Leguminosa secara Mikroskopis pada Lahan Olah Tanah Konservasi Musim Tanam ke 29. Jurnal Penelitian Pertanian Terapan, 17(1), 40-49

[24] Invam.(2010). Classification of Glomeromycota [terhubung berkala]. http://invam.caf.wvu.edu/ [18 September 2021].

[25] Wilson, J.M., Trinick, M.J., \& Parker, C.A. (1983). The Identification Vesicular-Arbuscular Mycorrhizal Fungi Using Immuno fluorescence. Soil Biology and Biochemistry, 15(4), 439-449. 